\title{
Digital Circumvention as a Means to Overcome Geographic Limitations: Defining the New Rural Entrepreneurial Ecosystem
}

\author{
Robert A. Lloyd \\ Fort Hays State University \\ Edward F. Vengrouskie \\ The Jack Welch Management Institute
}

Rural entrepreneurs have employed traditional marketing strategies to access markets, depended on news media, print literature, and word of mouth to gather information, utilized more traditional telecommunication modes to procure services not offered rurally, and relied on travel to expand their social network. These traditional enablers for rural entrepreneurs can now be circumvented vis-à-vis the digital affordances offered by new technologies. The developing literature on digital entrepreneurship reveals that digitization at the most rudimentary level is connecting entrepreneurial ecosystems and social networks (Autio, Nambisan, Llewellyn, \& Wright, 2017). Yet, the theoretical foundations of these connections remains under-researched and the competitive relevance of rural entrepreneurs needs to be re-examined in light of the enabling affordances of digital technologies. The purpose of this paper is to explore the literature on how digital technologies are enabling rural entrepreneurs as their own unique subset of the global entrepreneurial ecosystem.

Keywords: Rural Entrepreneurship, Digital Circumvention, Social Cognition, Rural Ecosystem

\section{INTRODUCTION}

Recent literature has portrayed digital technologies as disruptive innovation for the field of entrepreneurship and has characterized these technologies as a global equalizer because of low entry barriers and high accessibility as an entrepreneurial platform (Dy, Marlow, \& Martin, 2017; Nambisan, Lyytinen, Majchrzak, \& Song, 2017). Davidson and Vaast (2010) identified this phenomenon as digital entrepreneurship and defined the construct as "the pursuit of opportunities based on the use of digital media and other information and communication technologies" (p. 2). Digital entrepreneurship has led to an expanded entrepreneurial infrastructure resulting in the democratization of a greater number and more diverse constitution of entrepreneurs worldwide (Aldridge, 2014). Nambisan (2016) even suggests that our entire academic understanding of entrepreneurship needs to be re-thought, reframed, and reconsidered in light of the transformative nature of digital technologies on entrepreneurship.

Supporting these assumptions is the premise that diffusion of digitization has made entrepreneurial opportunities universally available (Mole \& Mole, 2010). Haraway (1989) concluded that the ubiquity of digitization should diminish social marginalization because it conceals the characteristics and identity of 
disadvantaged groups of entrepreneurs, resulting in a de facto meritocracy. A study conducted by Dy, Marlow, and Martin (2017) refuted this assumption and found that in spite of the disembodiment of entrepreneurs online, social marginalization still occurred. Given the only-recent emergence of digital entrepreneurship literature, the conclusion that disadvantaged groups now have equal access to opportunities needs to be explored.

Rural entrepreneurs have been characterized as geographically disadvantaged because they physically reside on the "periphery" (Rae, 2017), and this remoteness precludes them access to new-venture capital, professional networking, start-up accelerators, consumer markets, business incubators, and co-working spaces that urban areas offer (Acs \& Armington, 2006; Liang, 2014; Yu, Zhou, Wang, \& Xi, 2013; Korsgaard, Müller, \& Tanvig, 2015). Notwithstanding these significant economic disadvantages, rural populations have higher rates of entrepreneurship per 1,000 residents than metropolitan areas (U.S. BEA, 2017) and rural startups have a five year survival rate that is 10 percent higher than metropolitan startups (Thiede, Greiman, Weiler, Beda, \& Conroy, 2017). Digitization has mobilized entrepreneurs within this rural arena as an awakened collection of new competitors by diminishing or eliminating many of the traditional disadvantages bounded by geographic or physical factors. Nambisan (2016) offers that "digitization has led to less predefinition in the locus of entrepreneurial agency as it increasingly involves a broader, more diverse, and often continuously evolving set of actors - a shift from a predefined, focal agent to a dynamic collection of agents with varied goals, motives, and capabilities" (p. 2). We offer that the characteristics and behaviors of rural entrepreneurs as a traditionally marginalized group need better definition and contextualization within this shift from our previously defined understandings of entrepreneurship. Given their entrepreneurial proclivities and uniqueness as a subset of digital actors, the depth of their relevance to both research and practice needs to be understood in the digital milieu.

\section{Rural Ecosystem Defined}

Geographically, the Unites States is eighty percent rural and home to one in four Americans (U.S. Census Bureau, 2016), and is often studied in the context of its own economic and political characteristics (Lewis, 1979). The U.S. Census bureau makes a clear delineation between rural and urban for the purposes of their demographic reporting: population centers with fewer than 50,000 residents are considered rural areas. Autio, et al., (2017) defined an entrepreneurial ecosystem as a "digital economy phenomenon that harnesses technological affordances to facilitate entrepreneurial opportunity pursuit by new ventures through radical business model innovation" (p. 74). For the purposes of this study, we offer a contextualization of rural entrepreneurship within this definition of entrepreneurial ecosystem. Given their size, considerations for their unique characteristics, and access to the digital infrastructure, we argue that rural entrepreneurship would constitute a unique entrepreneurial ecosystem.

We term this the "rural ecosystem" and to operationalize its use in our study, we define it as the collection of individuals residing in population centers of 50,000 or fewer residents that leverage technological resources to pursue or operate entrepreneurial enterprises.

Empirical studies have characterized rural communities as disadvantaged in terms of digital accessibility and telecommunications infrastructure, leading some scholars include rural communities in the have-nots of the digital divide (Malecki, 2003; Townsend, Wallace, Fairhurst, \& Anderson, 2017; Hodge, Carson, Carson, Newman, \& Garrett, 2017). However, to our knowledge, no previous studies have investigated the impact of digitization on rural entrepreneurship. Many questions need to be answered in this regard. How will the rural ecosystem compete in the digital environment? How will rural entrepreneurs utilize and consume digital resources? Where will the rural ecosystem establish its presence in both supplier and consumer markets? More importantly, the interconnectedness of the global economy will have both a mitigating effect and moderating impact on small business (Lloyd, 2015). How will the rural ecosystem respond to this reality? Answering these questions is relevant not only to the

global community of entrepreneurs who now have to contend with a recently-endowed group of competitors but also to major corporations who are being challenged by competition that is operating in "increasingly porous and fluid boundaries" (Nambisan, 2016, p. 2). For example, Hilton now competes for room occupancy with micro-entrepreneurs offering their home for the weekend, made possible only 
through digital platforms such as Airbnb or Vacation Rentals by Owner. Start-up entrepreneurs in Silicon Valley and East Coast metropolises are competing with rural entrepreneurs for venture capital. Companies like Live, Give, Save, Inc. (Red Wing, MN population 16,000), Attently, Inc. (Fairbanks, AK population 32,000), and Windcall Manufacturing (Venando, NE, population 139) are vying for public investment on crowdfunding platforms like Kickstarter and Indiegogo. What is clear in this emerging digital economy is that the rural ecosystem is affecting the market in new ways. These phenomena need to be better understood.

Entrepreneurship has been conceptualized as a connection between the endogenous collection of individual entrepreneurs and the series of external networks and forces that influence them (Shane, 2003). As previously noted, the rural community has faced challenges in connecting to the urban economy. Limiting factors include access to markets, information, capital, services, and social networks (Liang, 2014; Yu, et al., 2013; Acs \& Armington, 2006; Liang, 2014; Korsgaard, et al., 2015). To be sure, the geographic peripherality of the rural entrepreneurs has inhibited this connection but does not eliminate it. Rural entrepreneurs have employed traditional marketing strategies to access markets, depended on news media, print literature, and word of mouth to gather information, utilized more traditional telecommunication modes to procure services not offered rurally, and relied on travel to expand their social network (Beeton, 2002; Schmid, 2004; Deakins, 2006; Mayer, Habersetzer, \& Meili, 2016; Witt, 2004; Muhyiddin \& Miskiyah, 2017; Neuwirth, 2012). These traditional enablers to accessibility are costly and require additional time and tacit knowledge to execute (Deakins, 2006). In this way, geographic isolation serves as a permeating barrier to accessibility.

Digital technologies have largely transformed this dynamic by allowing rural entrepreneurs to overcome many of these limitations. We term this digital circumvention and define it as the enabling effect of digital technologies on isolated entrepreneurs that allow them to bypass the permeating barrier of physical or geographic limitations. Nambisan (2016) proposes that digital technologies in the entrepreneurial environ are manifested in three particular modalities - digital infrastructure, digital platforms, and digital artifacts. He defined digital infrastructure as "digital technology tools and systems that offer communication, collaboration, and/or computing capabilities to support innovation and entrepreneurship" (p. 4). Within digital infrastructure, he includes examples such as cloud computing, data analytics, online communities, and social media. Digital platforms was defined as "a shared, common set of services and architecture that serves to host complementary offerings" (p. 4). Within digital platforms he includes examples such as Apple's IOS and Google's Android platforms that enable users to run software on their smartphones. A digital artifact was defined as "a digital component, application, or media content that is part of a new product (or service) and offers a specific functionality or value to the end-user" (p. 3). Examples include apps on a smartwatch and technology-enabled products such as Amazon's Dash button or the Nike+ Sensor. Each of these digital technology modes are allowing rural entrepreneurs to connect to the urban ecosystem in ways not possible vis-a-vis traditional enablers. Digital technologies diminish the permeating barrier of geographic peripherality. Figure 1 illustrates this relationship. 


\section{FIGURE 1 \\ TRADITIONAL ENABLERS AND DIGITAL TECHNOLOGIES CONNECTING RURAL AND URBAN ECOSYSTEMS}

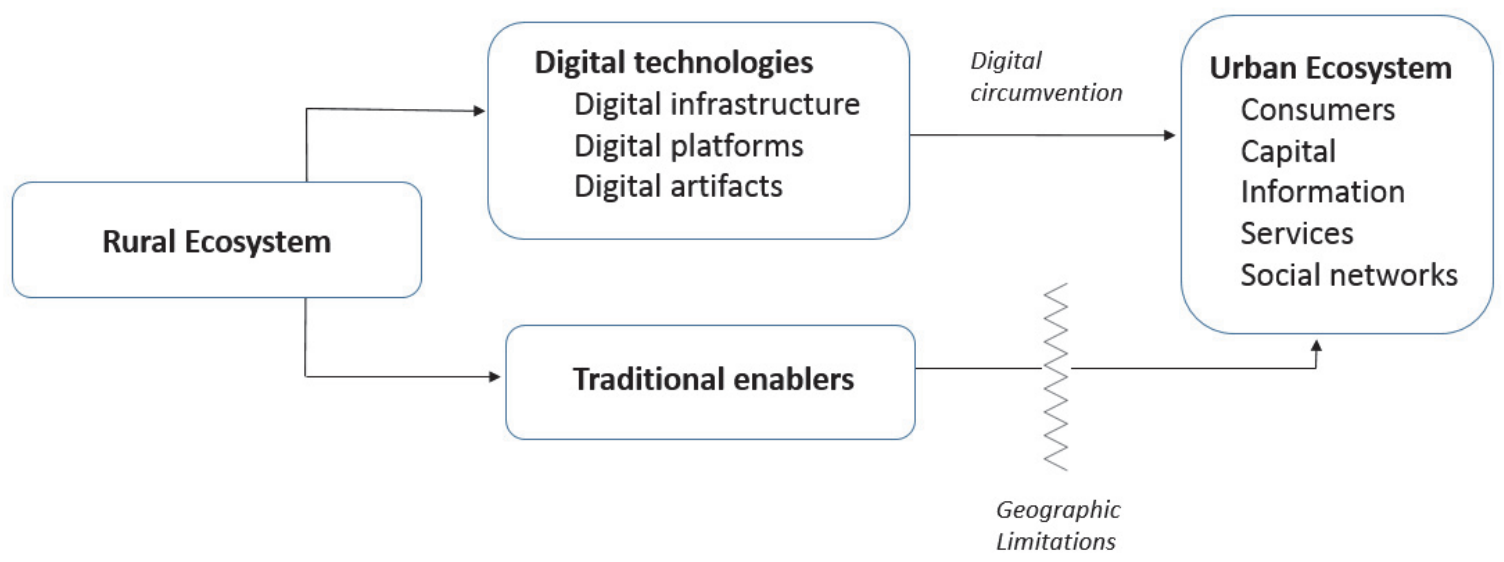

We have established thus far that rural entrepreneurship constitutes a unique ecosystem, and that digital technologies allow that ecosystem to connect with the urban ecosystem via digital circumvention. In the following section, we elucidate the theoretical framework we use to analyze how the rural ecosystem is using digital technologies to access the urban ecosystem.

As previously mentioned, digitization in the rural entrepreneurial ecosystem needs to be explored. Given the recent nascence of digital entrepreneurship literature, we find that addressing the rural component of digitization particularly relevant and timely. We begin this uncovering of digital entrepreneurship in rural communities by exploring how rural entrepreneurs learn in a digital environment. This locus is the most appropriate starting point because the concomitant outcomes associated with entrepreneurial learning can transform the distal nature of the rural ecosystem into competitive relevance. Across various samples and empirical settings, studies consistently report that learning has a positive influence on entrepreneurial outcomes. These include enhancement of the search and discovery process, progression of competencies to secure venture capital, lower mortality rates, increased operational efficiency, improved financial performance, and avoidance of previous mistakes (Venkataraman, 1997; Harrison \& Leitch, 2005; Reynolds \& White 1993; Anzai \& Simon, 1979; Chandler \& Jansen, 1992; Davidsson \& Honig 2003; Petkova, 2009). Furthermore, the positive cycle between learning and outcomes has an impact on the self-efficacy of entrepreneurs. Learning leads to positive outcomes, these outcomes lead to self-efficacy, and this self efficacy leads to higher aspirations and future performance improvements (Boyd \& Vozikis, 1994). Corollary to the focus on learning as an antecedent to self-efficacy, research also suggests that entrepreneurial self-efficacy is ensconced in social identity. An empirical study conducted by Brändle, Berger, Golla, and Kuckertz (2018), for example, discovered a link between social identity and the determinants of self-efficacy such as enactive mastery, role modeling, social persuasion, physical, and emotional state (Bandura, 1986). This social element also manifests itself in the financial impact of CSR efforts on firm performance as stakeholders respond to the social impact of businesses (Lloyd, 2017). In short, learning has an incontrovertible social element that impacts self-efficacy. The positive outcomes, self-efficacy, and consequent higher aspirations associated with learning will make the rural ecosystem relevant, and the environment in which they pursue this end draw our attention to the social identity. The link between learning and social context lead us to employ the theory of social cognition (Bandura, 1997; Wood \& Bandura, 1989; Bandura, 1986) as the theoretical founding for this study.

To achieve their transition to competitive relevance, the rural ecosystem is utilizing the ubiquitous affordances of digital technologies. Rural entrepreneurs are now afforded the opportunity to utilize digital 
platforms and digital infrastructure to learn from fellow entrepreneurs, industry experts, technical specialists, and practitioners in their field. For this reason, we find digitization and social cognition theory as especially compatible. In this section, establish the link between digitization and social cognition, and then contextualize the axioms of social cognition in order to establish our research questions.

\section{Social Cognition}

Bandura (1986) conceptualized social cognition as the "knowledge structures formed from the styles of thinking and behavior that are modeled from the outcomes of exploratory activities, verbal instruction, and innovative cognitive syntheses of acquired knowledge" (p. 24). Social cognition thus explains the mechanisms by which learning takes place when observing others and repeating their behaviors. Badura's (1997) foundational work on social cognition emphasizes the role that self-efficacy plays in this interchange inasmuch as successful integration of observed behaviors leads to higher levels of selfperceived confidence. Boyd and Vozikis (1994) posited that this self-efficacy derives from the gradual acquisition of complex cognitive, social, linguistic, and physical abilities obtained through direct experience of imitating others. Within this framework, three primary drivers contribute to self-efficacy vicarious experience, social experience, and mastery experience (Wood \& Badura, 1989). Erickson (2003) appropriately concluded that these components of social cognition not only contribute to entrepreneurial competence, but that a covariance between these variables intensifies entrepreneurial outcomes. That is, the most impactful learning takes place through the combined effect of observing and interacting with others. We focus on these elements of social cognition theory because rural entrepreneurs are afforded observational (vicarious), interactional (social), and practical (mastery) experiences with a collection of actors previously unavailable to them in the boundless environment described by Nambisan (2016).

Wood and Badura (1989) characterize vicarious experience as an observational learning model. This includes observation of peers and role models. Observing role models, for example can lead to high levels of reinforced self-efficacy as the learner makes social comparisons to aspirant behaviors. Boyd and Vozikis (1994) posit that entrepreneurial role models positively impact self-efficacy and this self-efficacy translates into higher levels of entrepreneurial intentions. Erickson (2002) connected this self-efficacy within vicarious experience to entrepreneurial competence which is to say that role models improve selfefficacy which lead to higher levels of actual entrepreneurial capabilities. Kolb, Osland, and Rubin (1995) impart the significance of self-reflection as a moderating variable in this relationship. Throughout each stage of observational learning, the learner reflects on their own behavior in light of their role model.

Communal influence on entrepreneurs characterizes the second element of social cognition (Wood \& Bandura, 1989). Social experience is the interaction with the realm of peers of the entrepreneur. Three fundamental drivers of social experience are imitation of behaviors, persuasion, and encouragement given to the entrepreneur from peers. These elements can lead entrepreneurs to elevate their perceptions of selfabilities and capabilities. Positive encouragement leads to improved efforts towards entrepreneurial goals. Boyd and Vozikis (1994) noted that social experience thus has a direct impact on self-efficacy, leading to higher levels of competence.

Mastery experience has the strongest influence on entrepreneurial self-efficacy (Wood \& Bandura, 1989). This is the "doing" component to learning as entrepreneurs gain valuable knowledge about processes and practical understandings of previous mistakes and successes. Lent and Hackett (1987) argue that mastery experience is impactful because they are confirmatory experiences that lead to estimations of future performances. Therefore, mastery experience directly influences self-efficacy. Wood and Bandura (1989) contend that increased self-efficacy leads to increased perseverance in future entrepreneurial challenges. MacGrath (1999) concluded that entrepreneurs with high self-efficacy associate failure with poor effort and entrepreneurs with low self-efficacy associate failure with poor ability. Because perceptions of success and failure are guided by cultural influences, mastery experience constitutes an element of social cognition (Erickson, 2002). Based on this understanding of vicarious, social, and mastery experience, more research needs to be done in this field. More specifically, the question needs to be answered: How do rural entrepreneurs use digital technologies to engage in 
vicarious, social, and mastery experience? The three elements of social cognition (vicarious, social, and mastery experiences) serve as the theoretical underpinnings for this research focus. Future research should draw upon these pillars, as the research explores their use in the digital context.

\section{CONCLUSION}

Badura's work on social cognition established the link between learners and their environment. The salient components of his work apply not only to established educational contexts, but in the social milieu of professional and industrial contexts (Lloyd \& Mertens, 2018). Rural entrepreneurs are leveraging the digital affordances to engage new ecosystems, and to expand their understanding and improve performance. The costs of traditional enablers that have acted as a hurdle for rural entrepreneurs is now dissipated by the much quicker and cheaper alternative of digital technology. These dynamics allow for a new conceptualization of what it means to be a rural entrepreneur.

\section{REFERENCES}

Acs, Z., \& Armington, C. (2006). Entrepreneurship, Geography, and American Economic Growth. Cambridge University Press: New York.

Aldrich, H. (2014). The democratization of entrepreneurship? Hackers, makerspaces, and crowdfunding. Annual Meeting of the Academy of Management, Philadelphia, August 2014.

Anzai, Y., \& Simon, H. A. (1979). The theory of learning by doing. Psychological Review, 86, 124-140.

Autio, E., Nambisan, S., Llewellyn, T., \& Wright, M. (2017). Digital affordance, spatial affordances, and the genesis of entrepreneurial ecosystems. Strategic Entrepreneurship Journal, 12(1), 72-95.

Bandura, A. (1986). Social foundations of thought and action : A social cognitive Theory. Englewood Cliffs, N.J.: Prentice-Hall.

Bandura, A. (1997). Self-Efficacy: The Exercise of Control. Freeman: New York, NY.

Beeton, S. (2002). Entrepreneurship in rural tourism? Australian Landcare programs as a destination marketing tool. Journal of Travel Research, 41(2), 206-209.

Boyd, N., \& Vozikis, G. S. (1994). The influence of self-efficacy on the development of entrepreneurial intentions and actions. Entrepreneurship Theory and Practice, 14(4), 63-77.

Brändle, L., Berger, E., Golla, S., \& Kuckertz, A. (2018). I am what I am: How nascent entrepreneurs' social identity affects their entrepreneurial self-efficacy. Journal of Business Venturing Insights, $8,17-23$

Browne, K. (2005). Snowball sampling: Using social networks to research non-heterosexual women. International Journal of Social Research Methodology, 8, 47-60.

Browne, K. (2005). Snowball sampling: Using social networks to research non-heterosexual women. International Journal of Social Research Methodology, 8, 47-60.

Chandler, G. N., \& Jansen, E. (1992). The founder's self-assessed competence and venture performance. Journal of Business Venturing, 7, 223-236.

Corbin, J., \& Strauss, A. (2008). Basics of qualitative research: Techniques and procedures for developing grounded theory. London, UK: Sage.

Corbin, J., \& Strauss, A. (2008). Basics of qualitative research: Techniques and procedures for developing grounded theory. London, UK: Sage.

Creswell, J. W. (2013). Qualitative inquiry and research Design: Choosing among five approaches (3 ${ }^{\text {rd }}$ ed.). Thousand Oaks, CA: Sage."

Davidson, E., \&Vaast, E (2010). Digital entrepreneurship and its sociomaterial enactment. In: System Sciences (HICSS), 2010 43rd Hawaii International Conference. Honolulu, HI, 58 January.

Davidsson, P., \& Honig, B. (2003). The role of social and human capital among nascent entrepreneurs. Journal of Business Venturing, 18, 301-331.

Deakins, D. (2006). Rural entrepreneurship - a distinctive field of study. International journal of entrepreneurial behavior \& research, 12(1). 
Dy, A., Marlow, S., \& Lee, M. (2017). A Web of opportunity or the same old story? Women digital entrepreneurs and intersectionality theory. Human Relations, 70(3), 286-311.

Elliot, C. (2016). Big hotels' plan to win customers from Airbnb. Fortune. Retrieved online at http://fortune.com/2016/01/27/big-hotels-airbnb/

Erikson, T. (2003). Towards a taxonomy of entrepreneurial learning experiences among potential entrepreneurs. Journal of Small Business and Enterprise Development, 10(1), 106-112.

Evans, D., \& Volery, T. (2001). Online business development services for entrepreneurs: An exploratory study. Entrepreneurship \& Regional Development, 13, 333-350.

Haraway, D. (1989). The biopolitics of postmodern bodies: Determinations of self in immune System discourse. differences: A Journal of Feminist Cultural Studies, 1(1), 3-43

Harrison, R. T., \& Leitch, C. M. (2005). Entrepreneurial learning: Researching the interface between learning and the entrepreneurial context. Entrepreneurship Theory and Practice, 29(4), 351-371.

Hodge, H., Carson, D., Carson, D., Newman, L., \& Garrett, J. (2017). Using Internet technologies in rural communities to access services: The views of older people and service providers. Journal of Rural Studies, 54, 469-478.

Kolb, D. A., Osland, J. S., \& Rubin, I. M. (1995). Organizational Behaviour - An experiential approach, 6th Ed. Prentice-Hall: Englewood Cliffs, NJ

Korsgaard, S., Ferguson, R., \& Graddefors, J. (2015). The best of both worlds: How rural entrepreneurs use placial embeddedness and strategic networks to create opportunities. Entrepreneurship \& Regional Development, 27, 574-598.

Korsgaard, S., Müller, S., \& Tanvig, H. (2015). Rural entrepreneurship or entrepreneurship in the rural between place and space. International Journal of Entrepreneurial Behavior \& Research, 21(1), $5-26$

Lent, R. W., \& Hackett, G. (1987). Career Self-Efficacy: Empirical Status and Future Directions. Journal of Vocational Behavior 30, 347-82."

Lewis, G. (1979). Rural communities (Problems in modern geography). London; North Pomfret, Vt.: David \& Charles.

Liang, C. (2014). Special issue: Rural Entrepreneurship. American Journal of Entrepreneurship, 7(2), 12.

Lloyd, R. A., \& Mertens, D. (2018). Expecting more out of Expectancy Theory: History urges inclusion of the social context. International Management Review, 14(1), 28-43.

Lloyd, R. A. (2017). The impact of CSR efforts on firm performance in the energy sector. Review of Integrative Business and Economics Research, 7(3), 25-65.

Lloyd, R. A. (2015). A brief history of globalized markets: Implications for managers. Journal for Global Business Education, 14, 5-11.

MacGrath, R. G. (1999). Failing forward: Real option reasoning and entrepreneurial failure. Academy of Management Review, 24(1), 13-30.

Malecki, E. (2003). Digital development in rural areas: Potentials and pitfalls. Journal of Rural Studies, 19(2), 201-214.

Mayer, H., Habersetzer, A., \& Meili, R. (2016). Rural-Urban Linkages and Sustainable Regional Development: The Role of Entrepreneurs in Linking Peripheries and Centers. Sustainability, 8(8), 745.

Mole, K. F., \& Mole, M. (2010). Entrepreneurship as the structuration of individual and opportunity: A response using a critical realist perspective: Comment on Sarason, Dean and Dillard. Journal of Business Venturing 25(2), 230-237.

Muhyiddin, N., \& Miskiyah, N. (2017). Rural urban linkages, fair trade and poverty in rural urban fringe. European Research Studies, 20(2A), 264-280.

Nambisan, S. (2017). Digital Entrepreneurship: Toward a Digital Technology Perspective of Entrepreneurship. Entrepreneurship Theory and Practice, 41(6), 1029-1055.

Nambisan, S., Lyytinen, K., Majchrzak, A., \& Song, M. (2017). Digital innovation management: Reinventing innovation management research in a digital world. MIS Quarterly, 41(1), 223-238. 
Nelson, J. (2016, December 14). Using conceptual depth criteria: addressing the challenge of reaching saturation in qualitative research. Qualitative Research, 1-17.

Neuwirth B. (2012). Marketing channel strategies in rural emerging markets: unlocking business potential. Evanston, IL: Kellogg School of Management.

Owen, W. F. (1984). Interpretive themes in relational communication. Quarterly Journal of Speech, 70, 274-287.

Petkova, A. (2009). A theory of entrepreneurial learning from performance errors. International Entrepreneurship and Management Journal, 5(4), 345-367.

Rae, D. (2017). Entrepreneurial learning: Peripherality and connectedness. International Journal of Entrepreneurial Behavior and Research, 23(3), 486-503.

Reynolds, P. D., \& White, S. (1993). Wisconsin's entrepreneurial climate study. Milwaukee, WI: Marquette University, Center for the Study of Entrepreneurship.

Schmid, A. A. (2004). Conflict and cooperation: Institutional and Behavioral Economics. Malden, MA: Blackwell Publishing.

Shane, S. (2003). A general theory of entrepreneurship: The individual-opportunity nexus. Cheltenham, England: Edward Elger Publishing

Thiede, B., Greiman, L., Weiler, S., Beda, S., \& Conroy, T. (2017). The divide between rural and urban America, in 6 charts. U.S. News. Retrieved from https://www.usnews.com/news/nationalnews/articles/2017-03-20/6-charts-that-illustrate-the-divide-between-rural-and-urban-america

Townsend, Wallace, Fairhurst, \& Anderson. (2017). Broadband and the creative industries in rural Scotland. Journal of Rural Studies, 54, 451-458.

Tracy, S. J. (2010). Qualitative quality: Eight "big-tent" criteria for excellent qualitative research. Qualitative Inquiry, 16, 837-851.

Tracy, S. J. (2013). Qualitative research methods: Collecting evidence, crafting analysis, communicating impact. Malden, MA: Wiley-Blackwell.

U.S. Census Bureau. (2016). Defining Rural at the U.S. Census Bureau: American Community Survey and Geography Brief. Retrieved from https://www2.census.gov/geo/pdfs/reference/ua/Defining_Rural.pdf

Venkataraman, S. (1997). The distinctive domain of entrepreneurship research: An editor's perspective. In J. Katz, \& R. Brockhaus (Eds.) Advances in entrepreneurship, firm emergence, and growth, (vol. 3, 119-138). Greenwich, CT: JAI.

Witt, P. (2004). Entrepreneurs' networks and the success of start-ups. Entrepreneurship \& Regional Development, 16(5), 391-412.

Wood, R., \& Bandura, A. (1989). Social cognitive theory of organisational management. Academy of Management Review, 14(3), 361-384.

Wortman, Max S., Jr. (1990). Rural entrepreneurship research: An integration into the entrepreneurship field. Agribusiness, 6(4), 329-345.

Yu, J., Zhou, J., Wang, Y., \& Xi, Y. (2013). Rural Entrepreneurship in an Emerging Economy: Reading Institutional Perspectives from Entrepreneur Stories. Journal of Small Business Management, 51(2), 183-195.

70 Journal of Strategic Innovation and Sustainability Vol. 14(4) 2019 